\title{
Assessment of Bronchial Lavage Samples For the Diagnosis of Childhood Pneumonia
}

\author{
Slobodanka Petrovic, Svetlana Cegar, Nenad Barisic* \\ Medical Faculty, University of Novi Sad, Pediatrics, Novi Sad, Serbia; Institute for Child and Youth Health Care of Vojvodina, \\ Novi Sad, Serbia
}

\begin{abstract}
Citation: Petrovic S, Cegar S, Barisic N. Assessment of Bronchial Lavage Samples For the Diagnosis of Childhood Pneumonia. OA Maced J Med Sci. 2014 Mar 15; 2(1):34-39. http://dx.doi.org/10.3889/oamjms.2014.006

Key words: pneumonia; pharyngolaryngeal aspirate; bronchial lavage; lower respiratory tract infections; bronchoscopy.

"Correspondence: Dr. Nenad Barisic. Medical Faculty, University of Novi Sad, Pediatrics. Hajduk Veljkova 3, Novi Sad 21000, Serbia. E-Mail: barisicnenadns@gmail.com

Received: 24-Sep-2013; Revised: 23-Nov2013; Accepted: 01-Dec-2013; Online first: 25-Dec-2013

Copyright: () 2013 Petrovic et al. This is an open-access article distributed under the terms of the Creative Commons Attribution License, which permits unrestricted use, distribution, and reproduction in any medium, provided the original author and source are credited.

Competing Interests: The authors have declared that no competing interests exist.
\end{abstract}

\begin{abstract}
Background: Lower respiratory tract infections are frequent and often serious diseases in children Wide number of microorganisms may cause lower respiratory tract infections, and sometimes it could be very difficult to determine the exact causative.
\end{abstract}

Aim: The aim of this study was to assess the reliability of specimens obtained by bronchial lavage in determining the etiology of childhood pneumonia.

Methods: This is prospective study conducted during four years period, in a group of 60 children aged from 6 months to 18 years. All patients included in this study underwent bronchoscopy when they fulfilled criteria of routine clinical protocol, in order to set correct diagnosis of lower respiratory tract disease. Results of bacteriological analysis of PLA samples were compared against the results of bacteriological analysis of $B L$ samples of the same patient.

Results: In majority of subjects - $41(68.32 \%)$, the bacteria isolated from the bronchial lavage samples was not identified in pharyngolaryngeal aspirate and was considered as the cause of infection. Haemophilus influenzae was the most frequently isolated pathogen in bronchial lavage samples.

Conclusion: Findings based on analysis of bronchial lavage samples may be used as reliable criterion for etiological diagnosis in cases of pneumonia when initial empirical treatment failed.

\section{Introduction}

Lower respiratory tract infections (LRTI), especially community acquired pneumonia (CAP), are frequent, worldwide spread and often serious diseases in children. In the developed world, the annual incidence of pneumonia is estimated to be 33 per 10,000 in children younger than five years and 14.5 per 10,000 in children 0 to 16 years [1]. In Europe, about 2.5 million children annually are diagnosed with CAP. The incidence is 10 times higher in developing countries. In addition to high frequency, childhood pneumonia is characterized by high mortality, contributing to 4-5 million deaths among children worldwide each year [2]. Wide number of microorganisms may cause LRTI, and sometimes it could be very difficult to determine the exact causative. Representative samples of sputum are rarely obtained from children, especially those of younger age [3]. The gold standard for determining the etiology of CAP in children - the bacteriological analysis of samples obtained by lung puncture or bronchoscopy is neither justified nor acceptable, except in severe and life threatening forms of disease [2]. Additional obstacle that makes identification of the cause of CAP difficult is colonization of the upper respiratory tract (URT) with pathogenic bacteria, what 
is common in children $[4,5]$. Increasing incidence of resistance to antibiotics emphasizes the need for reliable bacteriological diagnostics $[6,7]$.

The aim of this study was to assess the reliability of specimens obtained by bronchial lavage (BL) in determining the etiology of childhood pneumonia. Our assumption was that samples obtained by $B L$ are reliable and that these findings are applicable as guidance for the medical treatment.

\section{Methods}

We present results of prospective research conducted in a group of children treated at the Department of Pulmonology in a 4 years period. The study involved a total of 60 children, 26 females and 34 males, aged from 6 months up to 18 years (average 6.62 years, mode 4.83 years, median 5.25 years).

All patients included in this study underwent bronchoscopy when they fulfilled criteria of routine clinical protocol in order to set correct diagnosis of lower respiratory tract disease. The study included children with recurrent or persistent signs and symptoms and radiological findings that correspond to infection of lung parenchyma. Children included in the study had no any other underlying diseases. Subjects were included in the study only with previously obtained written informed consent of parents or legal guardians. The study had the approval of the ethics committee of the Institute for Child and Youth Health Care of Vojvodina.

For each patient, sampling of pharyngolaryngeal aspirate (PLA) was carried out just before bronchoscopy. PLA specimens were collected by standard aspiration technique; a catheter was placed in supraglottic region of the pharynx what caused reflex cough and consequential outflow of mucus from lower airways. The content was aspirated by a sterile syringe, injected in a sterile glass container and sent to bacteriological analysis. BL specimens were obtained by bronchial lavage during bronchoscopy and managed in the same manner as it is previously described [8]. Results of microbiological analysis of samples obtained by noninvasive means were compared against the results of bacteriological analysis of BL samples of the same patient. Patients with proven viral infections were excluded from the study.

Specimens (PLA and BL) were processed in the laboratory in the standard manner. After homogenization, undiluted specimens were sown on several culture media of standard composition: blood agar, chocolate agar, dextrose agar and saccharine agar. Substrates were incubated 18 to 24 hours at $37^{\circ}$ C. Growth and isolation of pathogenic or conditionally pathogenic bacteria in predominant number is considered as a positive finding. Predominant number indicates the number of colonies of certain bacterial species that is issued in the finding. Growth up to 30 colonies was qualified as a "small number", growth of 31-50 colonies was defined as "moderate number", while growth of over 50 colonies of certain bacterial species was considered as a "large number" of pathogenic or conditionally pathogenic bacteria. Isolation of pure bacterial culture (only one kind of bacteria), even in small number, was qualified as a positive finding [9].

On the bases of the PLA and BL findings, patients were divided into groups:

I. Normal oral flora isolated from PLA samples and sterile $\mathrm{BL}$ (normal/normal);

II. Two different bacterial species are isolated from PLA and BL samples ( $x$, y);

III. Normal flora isolated from PLA and only one type of bacteria isolated from BL samples (normal, $x$ );

IV. One type of bacteria isolated from PLA, but with sterile BL ( $x$, normal);

V. Same bacterial species are isolated in PLA and BL $(x, x)$;

VI. Two different types of bacteria ( $x$ and $y)$ isolated from PLA and only one type of bacteria isolated from $B L$ of which one was present in PLA ( $x$ or y);

VII. One type of bacteria present in PLA ( $x$ or $y$ ), and BL with two different types of bacteria of which one was present in PLA ( $x$ and $y$ ).

Bronchoscopy was performed with flexible or rigid bronchoscope. Flexible fiber-optic bronchoscope (Olympus P-20, external diameter $4.2 \mathrm{~mm}$ ) was used in collaborative patients older than 10 years. The intervention was performed under local anesthesia. Rigid bronchoscope (Karl Stortz) was used in all age groups in noncollaborative patients and procedure was performed under general anesthesia. Out of 60 patients included, 17 underwent flexible and 43 rigid bronchoscopy. When fiber-optic bronchoscope was used, the tip of fiber-optic tube was inserted into lobar or segmental estuary of the lobe or pulmonary segment in which pathological changes were detected by chest radiography. With rigid bronchoscope, broncholavage was performed by introducing the instrument in the main bronchus on the side where chest radiography findings were abnormal. Broncholavage was performed through the channel of the bronchoscope, with sterile metal aspiration catheter connected to a sterile bottle for lavate collection. In younger children a sterile plastic aspiration catheters were used. Immediately after use, the instrument was disassembled and all individual parts were disinfected. The instrument was sealed and kept in sterile cassette. Also, for the purpose of 
this study, before each intervention, we took swabs of the tube and sent them to microbiological analysis simultaneously with obtained BL samples. In all cases swabs were sterile.

Amount of liquid poured in the lower airways was determined pursuant to body weight (BW) of the patient: $\mathrm{BW} \leq 5 \mathrm{~kg}, 2 \mathrm{ml} 0.9 \% \mathrm{NaCl}$, heated at body temperature; BW 5-10 kg, $5 \mathrm{ml} 0.9 \% \mathrm{NaCl}$; BW 10-20 $\mathrm{kg}, 7 \mathrm{ml} \mathrm{0.9 \%} \mathrm{NaCl}$; BW $\geq 20$ kg, $10 \mathrm{ml} \mathrm{0.9 \%} \mathrm{NaCl}$.

The exact location of $\mathrm{BL}$ sampling was predetermined. In children with unilateral changes on CXRs and normal or pathologic bronchoscopic findings on the same lung, BL specimens were taken only from affected lung. In children with bilateral changes on CXRs and normal bronchoscopic findings, $\mathrm{BL}$ samples were taken from both lungs. In children with bilateral changes on CXRs and abnormal bilateral bronchoscopic findings, BL samples were taken from both lungs.

We assumed that the number of polymorphonuclear granulocytes and squamous buccal epithelial cells seen in a single microscope field under 100X magnification may confirm whether the specimens were retrieved from the upper or lower respiratory tract. Only specimens where squamous oral epithelial cells were not present and where number of polymorphonuclear leucocytes was $>25$ were considere [9-11]. The other criteria was the presence of bronchial ciliated epithelial cells, goblet cells, mucus and macrophages in amounts of 10 or more cells in one visual field at $100 \mathrm{X}$ magnification. All $\mathrm{BL}$ specimens satisfied these criteria.

Statistical testing is founded on the assessment of differences between frequency distributions in two samples; t- test of proportions, univariant analysis (ANOVA) and multivariant analysis (MANOVA) were used as appropriate statistical methods.

\section{Results}

In 31 (51.66\%) children normal oral bacterial flora was isolated from PLA, in 26 (43.33\%) cases one bacterial species, and in $3(5.00 \%)$ cases two bacterial species. BL cultures remained sterile in 8 (13.33\%) children, in 51 (85.00\%) children one bacterial species and in $1(1.66 \%)$ case two bacterial species were isolated. In 49 children results of PLA and $B L$ cultures were different. Bacteriological findings of PLA and BL samples in each group are shown in Table 1.

Table 1: Comparative results of bacteriological findings of PLA and BL samples.

\begin{tabular}{cccccccc}
\hline \multicolumn{7}{c}{ Groups of patients classified according to the paired findings of } \\
\cline { 2 - 9 } & $\mathrm{I}$ & $\mathrm{II}$ & $\mathrm{III}$ & $\mathrm{IV}$ & $\mathrm{V}$ & $\mathrm{VI}$ & $\mathrm{VII}$ \\
PLA & normal & $\mathrm{X}$ & normal & $\mathrm{X}$ & $\mathrm{X}$ & $\mathrm{X}, \mathrm{Y}$ & $\mathrm{X}$ \\
BL & sterile & $\mathrm{Y}$ & $\mathrm{X}$ & sterile & $\mathrm{X}$ & $\mathrm{X}$ & $\mathrm{X}, \mathrm{Y}$ \\
No & 6 & 16 & 25 & 2 & 7 & 3 & 1 \\
$\%$ & 10.00 & 26.66 & 41.66 & 3.33 & 11.66 & 5.00 & 1.66 \\
\hline
\end{tabular}

Frequency analysis with the differences between bacterial flora from PLA and BL specimens is shown in Table 2.

Table 2: Analysis of the frequencies of paired PLA and BL findings.

\begin{tabular}{|c|c|c|c|c|}
\hline \multicolumn{2}{|c|}{ Combinations of results PLA/BL } & \multicolumn{2}{|r|}{$\%$} & \multirow{2}{*}{$\frac{\mathbf{p}}{<0.05}$} \\
\hline & II & & 27.7 & \\
\hline \multirow[t]{3}{*}{ I } & $\begin{array}{l}\text { III } \\
\text { VII }\end{array}$ & 10.0 & 41.7 & $<0.05$ \\
\hline & III & & 41.7 & $<0.1$ \\
\hline & IV & & 3.3 & $<0.05$ \\
\hline \multirow[t]{4}{*}{ II } & $\mathrm{v}$ & 26.7 & 11.7 & $<0.05$ \\
\hline & VI & & 5.0 & $<0.05$ \\
\hline & VII & & 1.7 & $<0.05$ \\
\hline & IV & & 3.3 & $<0.05$ \\
\hline \multirow{3}{*}{ III } & v & & 11.7 & $<0.05$ \\
\hline & VI & 41.7 & 5.0 & $<0.05$ \\
\hline & VII & & 1.7 & $<0.05$ \\
\hline IV & $\mathbf{V}$ & 3.3 & 11.7 & $<0.1$ \\
\hline $\mathrm{V}$ & VII & 11.7 & 1.7 & $<0.05$ \\
\hline
\end{tabular}

Legend: PLA - pharyngolaryngeal aspirate; BL - bronchial lavage samples; I-VII - groups of patients classified according to the paired findings of PLA and BL; \% - percent of the total number of patients.

Data presented in Table 2 point out those bacteria cultured from PLA and BL samples were different in $26.7 \%$ of patients. That is significant difference compared to patients $(11.7 \%)$ with both specimens contaminated with identical kinds of bacteria $(p<0.05)$. There were more patients $(41.7 \%)$ with only $\mathrm{BL}$ cultures positive than patients $(11.7 \%)$ with positive findings of identical bacteria in both specimens $(p<0.05)$.

In majority of cases, bacteria isolated from PLA and BL samples of the same patient, were not congruen (Table 3).

Table 3: Review of incidence of congruent bacteria in PLA and BL specimens.

\begin{tabular}{ccccccc}
\hline & \multicolumn{6}{c}{ Congruent } \\
\cline { 2 - 7 } $\begin{array}{c}\text { Bacterial } \\
\text { culture } \\
\text { findings }\end{array}$ & \multirow{2}{*}{ Not } & $\begin{array}{c}\text { Hemo- } \\
\text { philus } \\
\text { influ- } \\
\text { enzae }\end{array}$ & $\begin{array}{c}\text { Strepto- } \\
\text { coccus } \\
\text { haemo- } \\
\text { lyticus }\end{array}$ & $\begin{array}{c}\text { Pseudo- } \\
\text { monas } \\
\text { aerugi- } \\
\text { nosa }\end{array}$ & $\begin{array}{c}\text { Brancha- } \\
\text { mella } \\
\text { catharralis }\end{array}$ & $\begin{array}{c}\text { Strepto- } \\
\text { coccus } \\
\text { pneu- } \\
\text { moniae }\end{array}$ \\
\hline No & 49 & 5 & 2 & 1 & 2 & 1 \\
\hline$\%$ & 81.67 & 8.33 & 3.33 & 1.67 & 3.33 & 1.67 \\
\hline
\end{tabular}

Legend: No - number of patients; \% - percent of the total number of patients.

Out of 60 patients included in the study, 46 (76.67\%) were previously treated with antibiotics. Comparative results of PLA and BL findings considering previous antibiotic treatment are shown in Table 4.

Table 4: Comparative results of PLA and BL findings considering previous antibiotic treatment.

\begin{tabular}{|c|c|c|c|c|c|c|c|}
\hline & & \multirow{2}{*}{\multicolumn{2}{|c|}{$\begin{array}{c}\text { PLA } \\
\begin{array}{c}\text { Previous antibiotic } \\
\text { treatment }\end{array} \\
\end{array}$}} & \multirow[b]{3}{*}{$\mathrm{p}$} & & $\mathrm{BL}$ & \multirow[b]{3}{*}{$\mathrm{p}$} \\
\hline & & & & & $\begin{array}{r}\text { Previo } \\
\text { tre }\end{array}$ & itibiotic & \\
\hline & & $\begin{array}{l}\text { yes } \\
(\%)\end{array}$ & $\begin{array}{l}\text { no } \\
(\%)\end{array}$ & & $\begin{array}{l}\text { yes } \\
(\%)\end{array}$ & $\begin{array}{l}\text { no } \\
(\%)\end{array}$ & \\
\hline \multirow{10}{*}{ 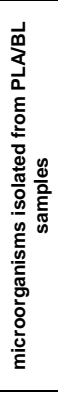 } & Normal oral flora & 52.2 & 57.1 & 0.745 & 13.0 & 14.3 & 0.905 \\
\hline & $\begin{array}{l}\text { Hemophilus } \\
\text { influenzae }\end{array}$ & 8.7 & 14.3 & 0.534 & 34.8 & 35.7 & 0.949 \\
\hline & $\begin{array}{l}\text { Streptococcus } \alpha \\
\text { haemolyticus }\end{array}$ & 13.0 & 7.1 & 0.549 & 13.0 & 7.1 & 0.549 \\
\hline & $\begin{array}{l}\text { Streptococcus } \\
\text { pneumoniae }\end{array}$ & 4.3 & 0.0 & 0.430 & 4.3 & 21.4 & 0.047 \\
\hline & $\begin{array}{l}\text { Klebsiella } \\
\text { pneumoniae }\end{array}$ & 4.3 & 0.0 & 0.430 & 0.0 & 0.0 & l \\
\hline & $\begin{array}{l}\text { Staphylococcus } \\
\text { pneumoniae }\end{array}$ & 0.0 & 7.1 & 0.072 & 0.0 & 0.0 & 1 \\
\hline & $\begin{array}{l}\text { Branchamella } \\
\text { catharralis }\end{array}$ & 4.3 & 0.0 & 0.430 & 4.3 & 0.0 & 0.430 \\
\hline & $\begin{array}{l}\text { Pseudomonas } \\
\text { aeruginosa }\end{array}$ & 2.2 & 7.1 & 0.368 & 17.4 & 7.1 & 0.350 \\
\hline & Escherichia coli & 0.0 & 7.1 & 0.072 & 0.0 & 0.0 & 1 \\
\hline & Candida & 2.2 & 0.0 & 0.580 & 0.0 & 7.1 & 0.072 \\
\hline
\end{tabular}


Univariant analysis and multivariant analysis of PLA and BL findings considering previously conducted empiric antibiotic therapy did not show statistical significance in majority of cases. Previous antibiotic therapy has not significantly affected oral bacterial flora (PLA findings). Also, previous empiric antibiotic therapy has not significantly affected results of majority of $\mathrm{BL}$ samples, except in cases where Streptococcus pneumoniae was isolated. This microorganism was more frequently isolated in children who have not received empiric antibiotic therapy.

\section{Discussion}

Despite the application of modern diagnostic procedures and the introduction of effective antimicrobial agents, bacterial lung infections remain significant medical and social problem. Childhood pneumonia is an important cause of morbidity in the developed world, and morbidity and mortality in the developing world [12]. Efficiency of the treatment of the LRTI depends on reliable identification of their etiology. The upper respiratory tract is colonized with more than 200 different bacterial species. These bacteria are normal, saprophytic microflora composed mainly of aerobic bacteria, among which the most significant are bacterial families like Neisseria, Streptococcus, Staphylococcus, Corine, and Haemophilus. Gram-negative bacteria (Pseudomonas and coliforms) aren't considered as normal habitants of the oral cavity and their number increases in hospitalized and immunocompromised patients. The trachea and bronchi are considered to be sterile, although some studies showed that $20 \%$ of tracheobronchial samples taken from healthy population contain small number of non-pathogenic bacteria [13].

Our assumption was that microbiological analysis of PLA specimens is not reliable method for determination of the ethiology of CAP and that findings are difficult to interpret due to possibility of contamination of the samples by the pharyngolaryngeal flora. It is also assumed that analysis of BL samples is sufficiently precise method for determination of the cause of infection. It must be noted that since there is a possibility of contamination during this intervention, suction catheters with doubleprotected brushes should be used to provide reliable sample collecting. However, due to economic reasons this is rarely applied [14-16].

Patients from group I had no pathogenic flora in PLA and BL cultures. Two children (3.33\%) had pathogenic bacteria in the PLA, but BL were sterile. In these patients, no bacteria entered the lower respiratory tract during the intubation.

Identical bacteria were found in the PLA and $\mathrm{BL}$ of 11 patients (groups $\mathrm{V}, \mathrm{VI}$ and $\mathrm{VII}$ ). That may be interpreted as contamination of the BL by the upper respiratory tract bacteria during the entry of the bronchoscope. However, these patients had radiological and clinical signs of respiratory disease, so we can not exclude the possibility of infection of upper and lower respiratory tract with the same microorganisms. Among them, 3 patients (group VI) had additional bacterial species in the PLA, which was not found in the BL, while one child (group VII) had one additional bacterial species in the BL which was not identified in the PLA culture before intubation. These findings support our stand to consider identified bacteria as the cause of the infection. In these patients there is a possibility that the same bacteria (present in the PLA and BL) initially caused the upper respiratory infection and spread onto the lower respiratory tract. In patients with clinical symptoms of the LRTI, and with identical culture results for PLA and $B L$ taken on the same day the interpretation of the results can be a problem. This is because there is a possibility of contamination via bronchoscope or bacteria spreading from the upper respiratory tract. In clinical practice it is often difficult to differentiate between bacterial "colonization" and "infection" of the respiratory tract. Colonization is defined as the presence of microorganisms without clear signs of inflammation. Bacterial colonization of normally sterile environments, such as the lower respiratory tract, is a specific problem. This situation is usually accompanied with signs of infection. Absence of signs of infection indicates to disorder of immune state of the host. When considering therapeutic options, beside findings obtained by culture analysis it is necessary to consider anamnesis (previous illnesses, clinical course, immunodeficiency, previous treatment, etc), clinical presentation, laboratory tests and chest radiography.

In $29.99 \%$ of patients with a positive PLA cultures (from groups II and IV), the bronchoscope was not the cause of the BL contamination, decidedly. Few studies proved that bronchoscopy is a reliable method and that possibility of bacterial contamination from upper respiratory tract is less than assumed [17, 18]. However, other authors believe that possibility of contamination of the samples obtained by bronchoscopy is a frequent problem in the interpretation of the results of BL and PAL culture [1921].

In group of children who underwent empiric antibiotic therapy prior to bronchoscopy Streptococcus pneumoniae was less frequently isolated in $\mathrm{BL}$ samples. However, this fact does not affect the validity of the findings since it may be assumed that previously or currently administered antibiotics did not eradicate the germs that cause currently active infection.

In majority of subjects - $41(68.32 \%)$ children, the bacteria isolated from the BL were not identified in PLA and were considered as the cause of infection. Haemophilus influenzae was the most frequently isolated pathogen in $\mathrm{BL}(34.8 \%$ of patients who did 
not received antibiotics prior $\mathrm{BL}$ vs. $35.7 \%$ of patients who received antibiotics prior BL). Research of De Schutter et al. showed similar results [22].

In some patients (group V), identical bacterial species were isolated from PLA and BL. This may be explained as contamination of $\mathrm{BL}$ with bacteria that originate from the upper respiratory tract and witch were inoculated in lower airways by the bronchoscope. However, there is a possibility that these bacteria colonized upper and lower respiratory tract at the same time causing acute respiratory infection and CAP.

As an appropriate interpretation of possible etiology of infection and assessment of risks for bronchoscopy-related contamination, following options should be considered:

A) If bacteria isolated from BL and PLA samples differ (group II) there was no contamination of the specimens taken from lower respiratory tract with oropharyngeal bacterial flora and isolated bacteria is most likely the cause of the lower respiratory tract infection.

B) If $B L$ is sterile, but PLA contains pathogenic flora (like in group IV) - the BL sample was not contaminated with oropharyngeal flora.

C) If PLA is sterile and bacterial colony growth is present in specimens obtained by $\mathrm{BL}$ (like in group III) than isolated bacterial species is the most likely cause of infection of the lower respiratory tract.

D) If the same bacteria were isolated in both specimens (like in group V) it may be considered as a possible cause of LRTI. But, the contamination could not be completely excluded.

E) In patients with two types of bacteria isolated in one of the specimens, of which one type is identical for BL and PLA specimens, it is most probably that "shared" bacteria was inoculated by the bronchoscope (like in groups VI, VII). The bacterial species which were isolated only from BL should be considered as possible cause of LRT infection (group VII).

When the results of the bacterial susceptibility patterns were available, therapy was adjusted according to the sensitivity of the bacteria. The results of the microbiological findings of specimens obtained by bronchoscopy made the choice of antibiotics easier and more accurate, what shorten the recovery period. It must be pointed out, even in patients who had positive cultures, the type of isolated microorganisms, length of prior therapy and clinical course of the disease, as well as other accompanying diseases must be considered when means of therapy are selected. Fein has published almost identical results, even though the testing included a heterogeneous group of 277 children and adults. [20] Godfrey has done a similar investigation in 109 children. The percentage of positive culture samples of $B L$ was lower than in our study - 26.6\% [21].

As a conclusion, bacteriological analysis of $\mathrm{BL}$ samples could be used as a sufficient and reliable criterion for diagnosis and treatment guidance in cases of pneumonia when initial empirical treatment failed. This faster etiologic diagnosis and increase the probability of appropriate antimicrobial therapy and reduce discordant therapy. The authors are aware that limitation of this study was relatively small sample size (a total of 60). For this reason findings cannot be generalized based on this study alone, but these findings provide the following insights for some future research.

\section{References}

1. Harris M, Clark J, Coote N, et al. British Thoracic Society guidelines for the management of community acquired pneumonia in children: update 2011. Thorax. 2011; 66(Suppl 2):ii1.

2. Stein R, Marostica P. Community - Acquired Bacteria Pneumonia. In: Chernick V, editor. Kendig's Disorders of Respiratory tract in Children. 7th ed. Philadelphia: Elsevier. 2006. p 441-452

3. Lahti E, Peltola V, Waris M et al. Induced Sputum In Diagnosis Of Childhood Community Acquired Pneumonia. Thorax. 2009; 64(3): 252-257

4. Masuda K, Masuda R, Nishi J. et al. Incidences of nasopharyngeal colonization of respiratory bacterial pathogens in Japanese children attending day-care centers. Pediatr Int. 2002; 44:376-380.

5. Bogaert D, van Belkum A, Sluijter $M$ et al. Colonisation by Streptococcus Pneumoniae and Staphylococcus Aureus in Healthy Children. Lancet. 2004; 363: 1871-1872.

6. Doern GV, Heilmann KP, Huynh HK. et al. Antimicrobial Resistance Among Clinical Isolates of Streptococcus Pneumonia in the United States During 1999-2000. Including a Comparasion of Resistance Rates Since 1994.-1995. Antimicrob Agents Chemother. 2001; 45: 1721-1729.

7. Jacobs MR, Johnson CE. Macrolide resistance: An increasing concern of treatment failure in children. Pediatr Infect Dis J. 2003; 22(Suppl 8): S 131-138.

8. Baselskin VS, Wunderink RG. Bronchoscopic Diagnosis of Pneumonia. Clin Microbiol Rev. 1994; 7(4): 533-558.

9. Budisin O, Sivcev J, Gusa N. Uporedjenje vrednosti dva načina obrade sputuma za kultivisanje u otkrivanju bakterijskih uzročnika obolenja donjih disajnih puteva. Saopštenje. 1982; 1-2:40-44.

10. Bartlett RC. Medical Microbiology: Quality Cost and Clinica Relevance. New York: John Wiley and Sons, 1974.

11. Geckler RW, Gremillion DH, Mc Allister CK, Ellenbogen C. Microscopic And Bacteriological Comparasion Of Paired Sputum And Tracheal Aspirates. J Clin Microbiol. 1977; 6: 396-399.

12. George WL, Finegold SM. Bacterial Infections of The Lung. Chest,. 1982; 81: 502-7.

13. Berman SZ, Mathison DA, Stevenson DD, Tan EM, Vaughan JH. Trancbronchial Aspirations Studies In Astmatic Patients In Relapse With „Infective“ Asthma And In Subjects Without Respiratory Disease. J Allergy Clin Immunol. 1975; 56:205214.

14. Wood A.Y,Davit A.J 2nd, Ciraulo D.L. et al. A prospective 
assessment of diagnostic efficacy of blind protective bronchial brushings compared to bronchoscope-assisted lavage, bronchoscope-directed brushings, and blind endotracheal aspirates in ventilator-associated pneumonia. J Trauma. 2003;55(5):825-34.

15. Meyer KC. Bronchoalveolar lavage as a diagnostic tool. Semin Respir Crit Care Med. 2007;28(5):546-60.

16. Sachdev A, Chugh K, Sethi M, Gupta D, Wattal C, Menon G. Diagnosis of ventilator-associated pneumonia in children in resource-limited setting: a comparative study of bronchoscopic and nonbronchoscopic methods. Pediatr Crit Care Med. 2010;11(2): 258-66.

17. Fagon J.Y, Chastre J, Wolff M, et al. Invasive and noninvasive strategies for management of suspected ventilator-associated pneumonia. A randomized trial. Ann Intern Med. 2000;132(8):621-30.

18. Chastre J. Diagnosis and treatment of nosocomial pneumonia: bronchial fibroscopy, protected brushing and/or bronchial lavage is indispensable. Rev Pneumol Clin. 2001;57(2):11323.

19. Chastre J, Trouillet J.L, Combes A, Luyt C.E. Diagnostic Techniques and Procedures for Establishing the Microbial Etiology of Ventilator-Associated Pneumonia for Clinical Trials: The Pros for Quantitative Cultures. Clin Infect Dis. 2010;51(Supp.1): S88-S92.

20. Fein AM, Feinsilver SH. Bronchoscopic Evaluation O Nonresolving And Slowly Resolving Pneumonia. J Bronchol. 1994; 1(4): 309-320.

21. Godfrey S, Avital A, Maayan C, Rotchild M, Springer C. Yeld From Flexibile Bronchoscopy In Children. Pediatr Pulmonol. 1997; 23(4): 261-269.

22. De Schutter I, De Wachter E, Crokaert F. et al. Microbiology of Bronchoalveolar Lavage Fluid in Children With Acute Nonresponding or Recurrent Community-Acquired Pneumonia: Identification of Nontypeable Haemophilus influenzae as a Major Pathogen. Clin Infect Dis 2011; 52(12): 1437-1444. 